\title{
Simultaneous Measurements of Heat Capacity, Electrical Re- sistivity and Hemispherical Total Emittance by a Pulse Heating Technique: Zirconium, 1500 to $2100 \mathrm{~K}^{*}$
}

\author{
A. Cezairliyan and F. Righini** \\ Institute for Materials Research, National Bureau of Standards, Washington, D.C. 20234
}

(February 26, 1974)

Simultaneous measurements of heat capacity, electrical resistivity and hemispherical total emittance of zirconium in the temperature range 1500 to $2100 \mathrm{~K}$ by a subsecond duration, pulse heating technique are described. The results are expressed by the relations:

$$
\begin{aligned}
C_{p} & =36.65-1.435 \times 10^{-2} T+6.624 \times 10^{-6} T^{2} \\
\rho & =87.95+1.946 \times 10^{-2} T \\
\epsilon & =0.2031+6.362 \times 10^{-5} T
\end{aligned}
$$

where $C_{p}$ is in $\mathrm{J} \cdot \mathrm{mol}^{-1} \cdot \mathrm{K}^{-1}, \rho$ is in $10^{-8} \Omega \cdot \mathrm{m}$, and $T$ is in $\mathrm{K}$. Estimated inaccuracies of the measured properties are: 3 percent for heat capacity, 2 percent for electrical resistivity and 5 percent for hemispherical total emittance.

Key words: Electrical resistivity; emittance; heat capacity; high-speed measurements; high temperature; thermodynamics; thermophysical properties; zirconium.

\section{Introduction}

In this paper, application of a pulse heating technique to the simultaneous measurements of heat capacity, electrical resistivity and hemispherical total emittance of zirconium in the temperature range 1500 to $2100 \mathrm{~K}$ is described.

The method is based on rapid resistive self-heating of the specimen from room temperature to high temperatures (above $1500 \mathrm{~K}$ ) in less than one second by the passage of an electrical current pulse through it; and on measuring, with millisecond resolution, such experimental quantities as current through the specimen, potential drop across the specimen, and specimen temperature. Details regarding the construction and operation of the measurement system, the methods of measuring experimental quantities, and other pertinent information, such as the formulation of relations for properties, error analysis, etc. are given in earlier publications $[1,2] .{ }^{1}$

\footnotetext{
*This work was supported in part by the U.S. Air Force Office of Scientific Research. **Guest scientist from the Istituto di Metrologia "G. Colonnetti" in Torino, under a fellowship from the Consiglio Nazionale delle Ricerche of Italy.

${ }^{1}$ Figures in brackets indicate the literature references at the end of this paper.
}

In the following sections of this paper a tabular format is adopted in presenting information on the specimen, measurements, system characteristics, results and errors.

\section{Measurements}

The details regarding the zirconium specimens used in the present measurements are given in table 1. A summary of the measurement technique and the operational characteristics of the system is given in table 2 . The polynomial functions (obtained by the least squares method) that represent the experimental results are given in table 3 . The values of properties at 100 degree temperature intervals computed using the functions are given in table 4 . The experimental results are presented in the appendix. Each number tabulated in the appendix represents results from over fifty original data points. An estimate of errors in the measured and computed quantities is given in table 5 . All values reported in this paper are based on the International Practical Temperature Scale of 1968 [3]. In all computations, the geometrical quantities are based on their room temperature $(298 \mathrm{~K})$ dimensions. 
TABLE 1. Specimen information

\begin{tabular}{|c|c|c|c|}
\hline No. & Item & Unit & Explanation \\
\hline 1 & Substance & & Zirconium \\
\hline 2 & Source $^{a}$ & & $\begin{array}{l}\text { Materials Research } \\
\text { Corporation. }\end{array}$ \\
\hline 3 & Purity & & $99.98 \%$ \\
\hline 4 & Impurities & & Listed in table $1 \mathrm{a}$. \\
\hline 5 & Geometry & & $\begin{array}{l}\text { Tube made from rod by } \\
\text { electro-erosion. }\end{array}$ \\
\hline \multirow[t]{6}{*}{6} & $\begin{array}{l}\text { Dimensions } \\
\text { (nominal) }\end{array}$ & & \\
\hline & total length & $\mathrm{mm}$ & 76.2 \\
\hline & effective ${ }^{\mathrm{b}}$ length & $\mathrm{mm}$ & 25.4 \\
\hline & outside diameter & $\mathrm{mm}$ & 6.3 \\
\hline & wall thickness & $\mathrm{mm}$ & 0.5 \\
\hline & blackbody hole & $\mathrm{mm}$ & $0.5 \times 1$ (rectangular) \\
\hline \multirow[t]{2}{*}{7} & Weight & & \\
\hline & total weight & $\underset{g}{g}$ & 4.312 \\
\hline \multirow[t]{3}{*}{8} & Characteristics & & \\
\hline & $\begin{array}{l}\text { atomic weight [4] } \\
\text { density }\end{array}$ & & $\begin{array}{r}91.22 \\
6.53\end{array}$ \\
\hline & $\begin{array}{l}\text { resistivity at } \\
293 \mathrm{~K}\end{array}$ & $10^{-8} \Omega \cdot \mathrm{m}$ & 42.8 \\
\hline
\end{tabular}

a The supplier is identified in this paper in order to adequately characterize the specimen. Such an identification does not imply recommendation or endorsement by the National Bureau of Standards.

${ }^{b}$ Effective refers to the portion of the specimen between the voltage probes.

${ }^{\mathrm{c}}$ Measured value in the present work.

TABLE la. Impurities in the specimen ${ }^{\text {a }}$

(according to the manufacturer's analysis)

\begin{tabular}{c|c|c|c|c|c|c|c|c|c|c}
\hline \hline Element & $\mathrm{C}$ & $\mathrm{H}$ & $\mathrm{O}$ & $\mathrm{N}$ & $\mathrm{Al}$ & $\mathrm{Fe}$ & $\mathrm{Hf}$ & $\mathrm{Ni}$ & $\mathrm{Si}$ & $\mathrm{Ti}$ \\
\hline $\mathrm{ppm}$ & 6 & 3.3 & 125 & 2.1 & 3 & 30 & 40 & 1.5 & 1.5 & 1 \\
\hline
\end{tabular}
limit.

${ }^{a}$ The total amount of all other detected elements is less than $6 \mathrm{ppm}$, each element being below $1 \mathrm{ppm}$ 
TABLE 2. Measurement technique and system characteristics

\begin{tabular}{|c|c|c|c|}
\hline No. & Item & Unit & Explanation and data \\
\hline $\begin{array}{l}1 \\
2 \\
3\end{array}$ & $\begin{array}{l}\text { General technique } \\
\text { Voltage measurement } \\
\text { Current measurement }\end{array}$ & & $\begin{array}{l}\text { Pulse heating (subsecond). } \\
\text { Across tungsten knife-edge probes. } \\
\text { Across standard resistor }(0.001 \Omega) \text { in series } \\
\text { with the specimen. }\end{array}$ \\
\hline $\begin{array}{l}4 \\
5 \\
6\end{array}$ & $\begin{array}{l}\text { Temperature measurement } \\
\text { Specimen environment } \\
\text { Power source }\end{array}$ & & $\begin{array}{l}\text { High-speed photoelectric pyrometer }[5] \text {. } \\
\text { Vacuum } \sim 1.3 \times 10^{-3} \mathrm{~N} \cdot \mathrm{m}^{-2}\left(\sim 10^{-5} \text { torr }\right) \text {. } \\
\text { Battery bank }(14 \text { series-connected } 2 \mathrm{~V} \text { batteries, } \\
\text { capacity } 1100 \mathrm{~A} \cdot \mathrm{h} \text { each }) .\end{array}$ \\
\hline $\begin{array}{l}7 \\
8 \\
9 \\
10 \\
11 \\
12 \\
13 \\
14\end{array}$ & $\begin{array}{l}\text { Recording } \\
\text { Signal resolution } \\
\text { Time resolution } \\
\text { Data processing } \\
\text { Number of specimens } \\
\text { Number of experiments } \\
\text { Temperature range } \\
\text { Temperature subranges }\end{array}$ & $\begin{array}{l}\mathrm{K} \\
\mathrm{K}\end{array}$ & $\begin{array}{l}\text { Digital data acquisition system. } \\
\sim 0.01 \text { percent (at full scale). } \\
0.4 \\
\text { Time-sharing computer. } \\
3 \\
12 \\
1500-2100 \\
\text { I }(1450-1680) \\
\text { II }(1680-1900) \\
\text { III }(1810-2050) \\
\text { IV }(1840-2110)\end{array}$ \\
\hline $\begin{array}{l}15 \\
16 \\
17 \\
18 \\
19 \\
20 \\
21 \\
22\end{array}$ & $\begin{array}{l}\text { Experiment duration } \\
\text { Current pulse length } \\
\text { Imparted power } \\
\text { Current } \\
\text { Rate of current change } \\
\text { Heating rate } \\
\text { Cooling rate } \\
\text { Radiative heat loss } \\
\text { (Percent of input power) }\end{array}$ & $\begin{array}{l}\mathrm{ms} \\
\mathrm{ms} \\
\mathrm{W} \\
\mathrm{A} \\
\mathrm{A} \cdot \mathrm{ms}^{-1} \\
\mathrm{~K} \cdot \mathrm{ms}^{-1} \\
\mathrm{~K} \cdot \mathrm{ms}^{-1}\end{array}$ & $\begin{array}{l}550-680 \\
350-480 \\
1700-3100 \\
730-840 \\
0.08-0.13 \\
2.9-4.8 \\
0.08-0.3 \\
2 \text { percent at } 1500 \mathrm{~K} \\
10 \text { percent at } 2100 \mathrm{~K}\end{array}$ \\
\hline
\end{tabular}

TABLE 3. Functional representation of results on zirconium

\begin{tabular}{c|cc}
\hline \hline $\begin{array}{c}\text { Heat capacity } \\
\left(\mathrm{J} \cdot \mathrm{mol}^{-1} \cdot \mathrm{K}^{-1}\right)\end{array}$ & $\begin{array}{c}\text { Resistivity } \\
\left(10^{-8} \Omega \cdot \mathrm{m}\right)\end{array}$ & $\begin{array}{c}\text { Hemispherical total } \\
\text { emittance }\end{array}$ \\
\hline$C_{p}=a+b T+\mathrm{c} T^{2}$ & $\rho=a+b T$ & $\epsilon=a+b T$ \\
$a=36.65$ & $a=87.95$ & $a=0.2031$ \\
$b=-1.435 \times 10^{-2}$ & $b=1.946 \times 10^{-2}$ & $b=6.362 \times 10^{-5}$ \\
$c=6.624 \times 10^{-6}$ & & \\
$1500 \mathrm{~K}<T<2100 \mathrm{~K}$ & $1500 \mathrm{~K}<T<2100 \mathrm{~K}$ & $\begin{array}{c}1650 \mathrm{~K}<T<2050 \mathrm{~K} \\
\sigma^{\mathrm{a}}=0.9 \%\end{array}$ \\
$\sigma^{\mathrm{a}=0.7 \%}$ & $\sigma^{\mathrm{a}=0.6 \%}$ & \\
\hline
\end{tabular}

${ }^{a}$ Standard deviation as computed from the difference between the value of an experimental result (as tabulated in the appendix) and that from the smooth functions reported above.

TABLE 4. Results on properties of zirconium

\begin{tabular}{c|c|c|r}
\hline \hline $\begin{array}{c}T \\
(\mathbf{K})\end{array}$ & $\begin{array}{c}C_{p} \\
\left(\mathrm{~J} \cdot \mathrm{mol}^{-1} \cdot \mathrm{K}^{-1}\right)\end{array}$ & $\begin{array}{c}\rho \\
\left(10^{-8} \Omega \cdot \mathrm{m}\right)\end{array}$ & \multicolumn{1}{|c}{} \\
\hline 1500 & 30.03 & 117.14 & ${ }^{a} 0.299$ \\
1600 & 30.65 & 119.09 & .305 \\
1700 & 31.40 & 121.03 & .311 \\
1800 & 32.28 & 122.98 & .318 \\
1900 & 33.30 & 124.92 & .324 \\
2000 & 34.45 & 126.87 & .330 \\
2100 & 35.73 & 128.82 & ${ }^{a} .337$ \\
\hline
\end{tabular}

${ }^{a}$ Extrapolated values.
TABLE 5. Error analysis (at $2000 \mathrm{~K}$ )

\begin{tabular}{l|c|c}
\hline \multicolumn{1}{c|}{ Quantity } & Imprecision $^{\mathrm{a}}$ & Inaccuracy $^{\mathrm{b}}$ \\
\hline Temperature & $0.5 \mathrm{~K}$ & $4 \mathrm{~K}$ \\
Voltage & $0.03 \%$ & $0.1 \%$ \\
Current & $0.03 \%$ & $0.1 \%$ \\
Heat capacity & $0.7 \%$ & $3 \%$ \\
Electrical resistivity & $0.6 \%$ & $2 \%$ \\
Hemispherical total emittance & $0.9 \%$ & $5 \%$ \\
\hline
\end{tabular}

${ }^{a}$ Imprecision refers to the standard deviation of a quantity as computed from the difference between the value of the quantity and that from the smooth function obtained by the least squares method. The quantities in the case of temperature, voltage, and current are the individual points measured in a single experiment, and in the case of heat capacity, electrical resistivity, and hemispherical total emittance are the results from all experiments as tabulated in the appendix.

${ }^{b}$ Inaccuracy refers to the estimated total error (random and systematic).

\section{Discussion}

The differences in the measured properties for the three specimens were within the measurement resolution for the properties, and the final smoothed results (represented by the equations in table 3 and tabulations in table 4) were obtained from the combined data for the three specimens. The heat capacity, electrical 
resistivity and hemispherical total emittance of zirconium measured in this work are presented and compared graphically with those reported in the literature in figures 1,2 , and 3 , respectively. The present results are for temperatures up to $2100 \mathrm{~K}$, which is approximately $30 \mathrm{~K}$ below the melting point of zirconium.

The heat capacity results of this work are approximately 1 percent lower than those of Skinner [6] in the overlapping temperature region. Extrapolation of the results of this work to lower temperatures (1200$1400 \mathrm{~K}$ ) yields values which are 3-6 percent lower than those reported by Coughlin and King [7]. However, too much significance should not be attached to the latter since: (a) the comparison is based on an extrapolation of 100 to $300 \mathrm{~K}$ and (b) the constant heat capacity reported by Coughlin and King [7] is not realistic.

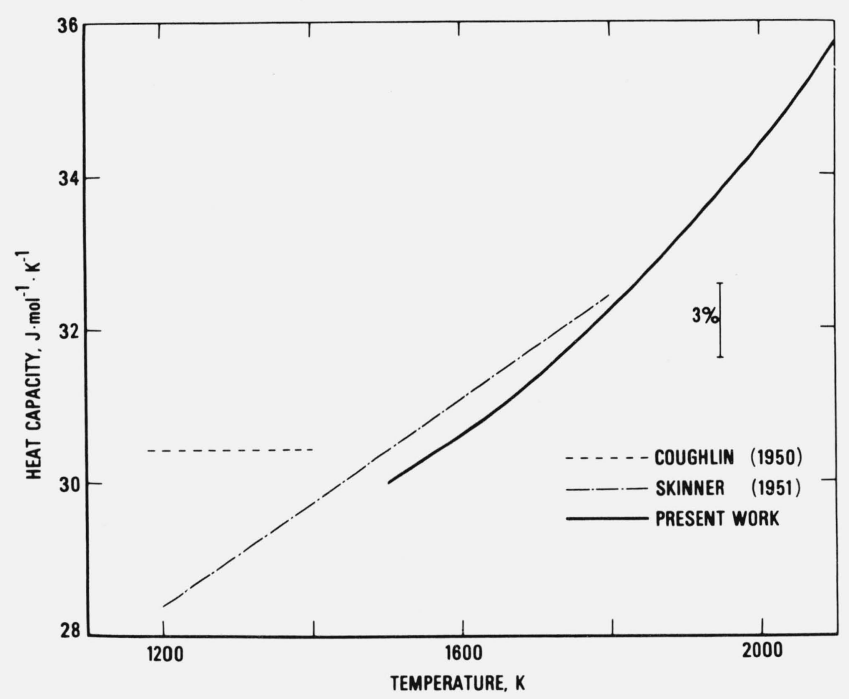

FigURE 1. Heat capacity of zirconium reported in the literature.

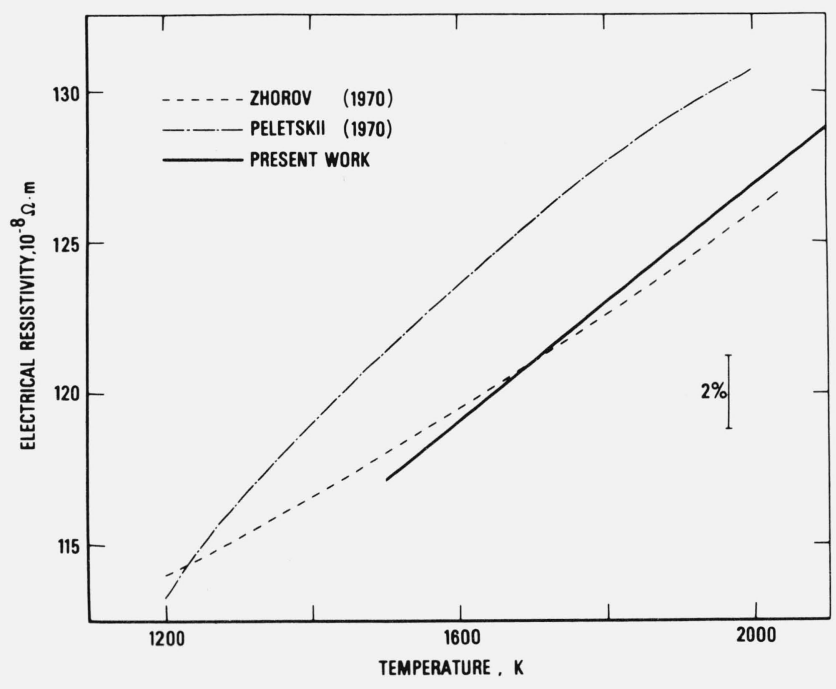

FIGURE 2. Electrical resistivity of zirconium reported in the literature.

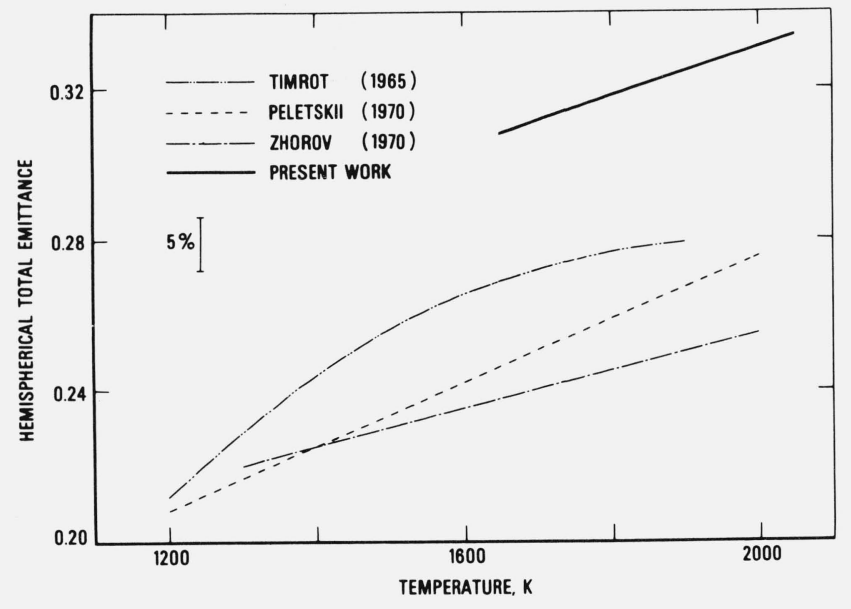

FigURE 3. Hemispherical total emittance of zirconium reported in the literature.

The electrical resistivity results are in reasonably good agreement (maximum difference less than 1 percent) with those of Zhorov [8], and are approximately 3-4 percent lower than those of Peletskii et al. [9], in the overlapping temperature regions.

Zirconium undergoes a solid-solid phase transformation around $1150 \mathrm{~K}$. The measurements of the geometrical quantities of the specimen after a number of experiments indicated permanent distortions (elongation) due to repeated heating and cooling through the transformation point. The reported electrical resistivity results are corrected for the permanent geometrical changes. The magnitude of this correction was about 1 percent. At $293 \mathrm{~K}$, the average electrical resistivity $\left(42.8 \times 10^{-8} \Omega \cdot \mathrm{m}\right)$ of the three specimens used in this work is within 3.5 percent of the values reported in the literature by Adenstedt [10] $\left(44.1 \times 10^{-8}\right.$ $\Omega \cdot \mathrm{m})$ and by Powell and Tye [11] $\left(42.2 \times 10^{-8} \Omega \cdot \mathrm{m}\right.$ and $44.3 \times 10^{-8} \Omega \cdot \mathrm{m}$ ). Some of the differences in the electrical resistivity values may be due to differences in the chemical composition of the specimens.

The hemispherical total emittance values reported in this work are higher $(10-25 \%)$ than those reported by Timrot and Peletskii [12], Peletskii et al. [9], and Zhorov [8]. Considerable differences in hemispherical total emittance results of various investigators may be due to differences in specimen surface conditions. Changes in the specimens' surface conditions were noticed during this work, with the initial smooth polished surface changing to an uneven rough surface as the result of repeated heating and cooling through the transformation point. This may partially account for the high emittance values.

The authors express their gratitude to C. W. Beckett for his encouragement of research in high-speed thermophysical measurements and to M. S. Morse for his help with the electronic instrumentation. 


\section{Appendix}

TABLE A-1. Experimental results on heat capacity of zirconium

\begin{tabular}{|c|c|c|c|c|c|c|c|c|c|}
\hline \multirow{2}{*}{ Range } & \multirow{2}{*}{$\begin{array}{c}\text { Temperature } \\
(\mathrm{K})\end{array}$} & \multicolumn{2}{|c|}{ Specimen-1 } & \multicolumn{2}{|c|}{ Specimen-2 } & \multicolumn{4}{|c|}{ Specimen-3 } \\
\hline & & $\begin{array}{c}C_{p}(\mathrm{~J} \cdot \\
\left.\mathrm{mol}^{-1} \cdot \mathrm{K}^{-1}\right)\end{array}$ & $\begin{array}{c}\Delta C_{p}{ }^{*} \\
(\%)\end{array}$ & $\begin{array}{c}C_{p}(\mathrm{~J} \cdot \\
\left.\mathrm{mol}^{-1} \cdot \mathrm{K}^{-1}\right)\end{array}$ & $\begin{array}{l}\Delta C_{p}{ }^{*} \\
(\%)\end{array}$ & $\begin{array}{c}C_{p}(\mathrm{~J} \cdot \\
\left.\mathrm{mol}^{-1} \cdot \mathrm{K}^{-1}\right)\end{array}$ & $\begin{array}{c}\Delta C_{p}{ }^{*} \\
(\%)\end{array}$ & $\begin{array}{c}C_{p}(\mathrm{~J} \cdot \\
\left.\mathrm{mol}^{-1} \cdot \mathrm{K}^{-1}\right)\end{array}$ & $\begin{array}{c}\Delta C_{p}{ }^{*} \\
(\%)\end{array}$ \\
\hline I & $\begin{array}{l}1500 \\
1550 \\
1600 \\
1650\end{array}$ & $\begin{array}{l}29.87 \\
30.38 \\
30.91 \\
31.45\end{array}$ & $\begin{array}{l}-0.52 \\
+0.20 \\
+0.86 \\
+1.42\end{array}$ & $\begin{array}{l}29.72 \\
30.16 \\
30.61 \\
31.05\end{array}$ & $\begin{array}{l}-1.03 \\
-0.53 \\
-0.11 \\
+0.15\end{array}$ & $\begin{array}{l}29.73 \\
30.22 \\
30.72 \\
31.22\end{array}$ & $\begin{array}{l}-1.00 \\
-0.33 \\
+0.25 \\
+0.69\end{array}$ & $\begin{array}{l}30.02 \\
30.38 \\
30.72 \\
31.65\end{array}$ & $\begin{array}{l}-0.02 \\
+0.20 \\
+0.25 \\
+2.04\end{array}$ \\
\hline II & $\begin{array}{l}1700 \\
1750 \\
1800 \\
1850 \\
1900\end{array}$ & $\begin{array}{l}31.54 \\
32.05 \\
32.57\end{array}$ & $\begin{array}{l}+0.46 \\
+0.72 \\
+0.90\end{array}$ & $\begin{array}{l}31.10 \\
31.79 \\
32.22\end{array}$ & $\begin{array}{l}-0.95 \\
-0.10 \\
-0.18\end{array}$ & $\begin{array}{l}31.32 \\
31.79 \\
32.25 \\
32.71 \\
33.17\end{array}$ & $\begin{array}{l}-0.24 \\
-0.10 \\
-0.09 \\
-0.18 \\
-0.37\end{array}$ & $\begin{array}{l}31.32 \\
31.83 \\
32.36 \\
32.89 \\
33.42\end{array}$ & $\begin{array}{l}-0.24 \\
+0.03 \\
+0.25 \\
+0.37 \\
+0.38\end{array}$ \\
\hline III & $\begin{array}{l}1850 \\
1900 \\
1950 \\
2000 \\
2050\end{array}$ & $\begin{array}{l}32.66 \\
33.31 \\
33.99 \\
34.70 \\
35.44\end{array}$ & $\begin{array}{l}-0.34 \\
+0.05 \\
+0.41 \\
+0.74 \\
+1.05\end{array}$ & $\begin{array}{l}32.42 \\
33.05 \\
33.72 \\
34.40\end{array}$ & $\begin{array}{l}-1.08 \\
-0.74 \\
-0.39 \\
-0.12\end{array}$ & & & & \\
\hline IV & $\begin{array}{l}1850 \\
1900 \\
1950 \\
2000 \\
2050 \\
2100\end{array}$ & $\begin{array}{l}32.96 \\
33.21 \\
33.63 \\
34.25 \\
35.12 \\
36.31\end{array}$ & $\begin{array}{l}+0.58 \\
-0.25 \\
-0.66 \\
-0.56 \\
+0.15 \\
+1.62\end{array}$ & $\begin{array}{l}32.77 \\
33.02 \\
33.43 \\
34.01 \\
34.79 \\
35.82\end{array}$ & $\begin{array}{r}0.00 \\
-0.83 \\
-1.26 \\
-1.27 \\
-0.79 \\
+0.27\end{array}$ & & & & \\
\hline
\end{tabular}

* The quantity $\Delta C_{p}$ is percentage deviation of the individual results from the smooth function represented by the pertinent equation in table 3 .

TABLE A-2. Experimental results on electrical resistivity of zirconium

\begin{tabular}{|c|c|c|c|c|c|c|c|c|c|}
\hline \multirow{2}{*}{ Range } & \multirow{2}{*}{$\begin{array}{c}\text { Temperature } \\
(\mathrm{K})\end{array}$} & \multicolumn{2}{|c|}{ Specimen-1 } & \multicolumn{2}{|c|}{ Specimen-2 } & \multirow[b]{2}{*}{$\stackrel{\rho}{\rho} \stackrel{\left(10^{-8} \Omega \cdot \mathrm{m}\right)}{ }$} & \multicolumn{2}{|c|}{ Specimen-3 } & \multirow[b]{2}{*}{$\begin{array}{l}\Delta \rho^{*} \\
(\%)\end{array}$} \\
\hline & & $\begin{array}{c}\rho \\
\left(10^{-8} \Omega \cdot m\right)\end{array}$ & $\begin{array}{l}\Delta \rho^{*} \\
(\%)\end{array}$ & $\begin{array}{c}\rho \\
\left(10^{-8} \Omega \cdot \mathrm{m}\right)\end{array}$ & $\begin{array}{l}\Delta \rho^{*} \\
(\%)\end{array}$ & & $\begin{array}{l}\Delta \rho^{*} \\
(\%)\end{array}$ & $\begin{array}{c}\rho \\
\left(10^{-8} \Omega \cdot \mathrm{m}\right)\end{array}$ & \\
\hline I & $\begin{array}{l}1500 \\
1550 \\
1600 \\
1650\end{array}$ & $\begin{array}{l}115.97 \\
117.06 \\
118.14 \\
119.25\end{array}$ & $\begin{array}{l}-1.02 \\
-0.91 \\
-0.81 \\
-0.69\end{array}$ & $\begin{array}{l}116.07 \\
117.16 \\
118.30 \\
119.39\end{array}$ & $\begin{array}{l}-0.93 \\
-0.82 \\
-0.67 \\
-0.57\end{array}$ & $\begin{array}{l}117.55 \\
118.62 \\
119.75 \\
120.87\end{array}$ & $\begin{array}{l}+0.34 \\
+0.42 \\
+0.54 \\
+0.66\end{array}$ & $\begin{array}{l}117.67 \\
118.85 \\
119.98 \\
121.10\end{array}$ & $\begin{array}{l}+0.44 \\
+0.61 \\
+0.74 \\
+0.85\end{array}$ \\
\hline II & $\begin{array}{l}1700 \\
1750 \\
1800 \\
1850 \\
1900\end{array}$ & $\begin{array}{l}120.36 \\
121.41 \\
122.50\end{array}$ & $\begin{array}{l}-0.57 \\
-0.50 \\
-0.40\end{array}$ & $\begin{array}{l}120.50 \\
121.56 \\
122.57\end{array}$ & $\begin{array}{l}-0.45 \\
-0.38 \\
-0.34\end{array}$ & $\begin{array}{l}122.00 \\
123.06 \\
124.10 \\
125.13 \\
126.14\end{array}$ & $\begin{array}{l}+0.78 \\
+0.85 \\
+0.89 \\
+0.93 \\
+0.95\end{array}$ & $\begin{array}{l}122.00 \\
123.07 \\
124.10 \\
125.13 \\
126.23\end{array}$ & $\begin{array}{l}+0.78 \\
+0.86 \\
+0.89 \\
+0.93 \\
+1.02\end{array}$ \\
\hline III & $\begin{array}{l}1850 \\
1900 \\
1950 \\
2000 \\
2050\end{array}$ & $\begin{array}{l}123.60 \\
124.62 \\
125.65 \\
126.68 \\
127.71\end{array}$ & $\begin{array}{l}-0.29 \\
-0.25 \\
-0.21 \\
-0.16 \\
-0.12\end{array}$ & $\begin{array}{l}123.61 \\
124.60 \\
125.59 \\
126.58\end{array}$ & $\begin{array}{l}-0.29 \\
-0.27 \\
-0.26 \\
-0.24\end{array}$ & & & & \\
\hline IV & $\begin{array}{l}1850 \\
1900 \\
1950 \\
2000 \\
2050 \\
2100\end{array}$ & $\begin{array}{l}123.60 \\
124.64 \\
125.65 \\
126.63 \\
127.61 \\
128.61\end{array}$ & $\begin{array}{l}-0.29 \\
-0.24 \\
-0.21 \\
-0.20 \\
-0.19 \\
-0.17\end{array}$ & $\begin{array}{l}123.61 \\
124.67 \\
125.68 \\
126.66 \\
127.62 \\
128.59\end{array}$ & $\begin{array}{l}-0.29 \\
-0.21 \\
-0.18 \\
-0.18 \\
-0.19 \\
-0.19\end{array}$ & & & & \\
\hline
\end{tabular}

*The quantity $\Delta \rho$ is percentage deviation of the individual results from the smooth function represented by the pertinent equation in table 3 . 
TABLE A-3. Experimental results on hemispherical total emittance of zirconium

\begin{tabular}{c|c|c||c|c|c}
\hline \hline \multicolumn{3}{c||}{ Specimen-1 } & \multicolumn{3}{c}{ Specimen-2 } \\
\hline $\begin{array}{c}\text { Tempera- } \\
\text { ture (K) }\end{array}$ & $\epsilon$ & $\begin{array}{c}\Delta \epsilon^{\mathrm{a}} \\
(\%)\end{array}$ & $\begin{array}{c}\text { Tempera- } \\
\text { ture (K) }\end{array}$ & $\epsilon$ & $\begin{array}{c}\Delta \epsilon^{\mathrm{a}} \\
(\%)\end{array}$ \\
\hline 1674.7 & 0.307 & -0.87 & 1650.5 & 0.301 & -2.37 \\
1680.1 & .309 & -0.33 & 1655.5 & .304 & -1.47 \\
1685.7 & .310 & -0.12 & 1660.7 & .307 & -0.58 \\
1691.4 & .312 & +0.40 & 1666.0 & .310 & +0.28 \\
1697.1 & .313 & +0.61 & 1671.4 & .312 & +0.81 \\
1703.0 & .314 & +0.80 & 1676.9 & .315 & +1.65 \\
1848.8 & .320 & -0.24 & 1980.7 & .326 & -0.96 \\
1856.9 & .322 & +0.23 & 1991.0 & .327 & -0.86 \\
1865.3 & .324 & +0.68 & 2001.6 & .328 & -0.75 \\
1873.7 & .325 & +0.82 & 2012.3 & .329 & -0.65 \\
1882.4 & .327 & +1.26 & 2023.3 & .329 & -0.87 \\
1891.3 & .328 & +1.39 & 2034.5 & .330 & -0.78 \\
2003.3 & .330 & -0.18 & & & \\
2014.3 & .332 & +0.22 & & & \\
2025.6 & .333 & +0.30 & & & \\
2037.1 & .334 & +0.38 & & & \\
2048.9 & .335 & +0.45 & & & \\
2061.0 & .336 & +0.52 & & & \\
\hline
\end{tabular}

a The quantity $\Delta \epsilon$ is percentage deviation of the individual results from the smooth function represented by the pertinent equation in table 3.

\section{References}

[1] Cezairliyan, A., Design and operational characteristics of a high-speed (millisecond) system for the measurement of thermophysical properties at high temperatures, J. Res. Nat. Bur. Stand. (U.S.) 75C (Eng. and Instr.), No. 1, 7 (1971).
[2] Cezairliyan, A., Morse, M. S.. Berman, H. A.. and Beckett, C. W., High-speed (subsecond) measurement of heat capacity, electrical resistivity, and thermal radiation properties of molybdenum in the range 1900 to $2800 \mathrm{~K}$, J. Res. Nat. Bur. Stand. (U.S.) 74A (Phys. and Chem.) No. 1, 65-90 (Jan.Feb. 1970).

[3] International Practical Temperature Scale of 1968, Metrologia 5, 35 (1969).

[4] IUPAC Commission on Atomic Weights, Atomic weights of the elements 1969. Pure Appl. Chem. 21, 91 (1970).

[5] Foley, G. M., High-speed optical pyrometer, Rev. Sci. Instr. 41, 827 (1970).

[6] Skinner, G. B., Thermodynamic and structural properties of zirconium, Ph.D. Thesis, Ohio State University, 1951.

[7] Coughlin, J. P., and King, E. G., High-temperature heat contents of some zirconium-containing substances, J. Am. Chem. Soc. 72, 2262 (1950)

[8] Zhorov, G. A., Emissivity of metals of the IVb subgroup at high temperatures. High Temp. 8, 501 (1970).

[9] Peletskii, V. É., Druzhinin, V. P., and Sobol', Ya. G., Emissivity, thermal conductivity, and electrical conductivity of remelted zirconium at high temperatures, High Temp. 8 , 732 (1970).

[10] Adenstedt, H. K., Physical, thermal and electrical properties of hafnium and high purity zirconium, Trans. A.S.M. 44, 949 (1952).

[11] Powell, R. W., and Tye, R. P., The thermal and electrical conductivities of zirconium and of some zirconium alloys. J. Less-Common Metals 3, 202 (1961).

[12] Timrot, D. L., and Peletskii, V. E., The thermal conductivity and integral blackness of zirconium, High Temp. 3, 199 (1965).

(Paper 78A4-831) 